\title{
Optimization of bioselective membrane of amperometric enzyme sensor on basis of glucose oxidase using $\mathrm{NH}_{2}$-modified multi-wall carbone nanotubes
}

\author{
O. A. Biloivan, N. S. Rogaleva, Y. I. Korpan
}

Institute of Molecular Biology and Genetics NANU, Kyiv

150 Zabolotnogo str. Kyiv 03680 Ukraine

o.a.biloivan@imbg.org.ua

\begin{abstract}
Aim. To investigate a possibility of application of multi-wall carbone nanotubes modified with $\mathrm{NH}_{2}$-groups $\left(\mathrm{MWCNT}-\mathrm{NH}_{2}\right)$ for creation of sensitive elements of the amperometric biosensor based on immobilized oxidoreductases, in particular, glucose oxidase (GOD). To study electrochemical properties of the membranes obtained. Methods. Experiments were carried out with am-perometric methods using the MStat 200 device ("DropSens», Spain). The enzymes were immobilised in glutaraldehyde vapour. Results. The method of formation of bioselective matrix based on immobilised GOD with $\mathrm{MNP}-\mathrm{NH}_{2}$ on the surface of gold ampe-rometric electrodes was optimised. Optimal working conditions of the biosensor developed were determined. Conclusion. MWCNT integration into a bioselective matrix improves the biosensor analytical characteristics which means: higher signal value, wider linear range of glucose analysis, and possibility of substrate determination in wide range of working potential.
\end{abstract}

Keywords: $\mathrm{NH}_{2}$-modified multi-wall carbone nanotubes, amperometric biosensor, oxidoreductase, glucose oxidase.

Currently, worldwide scientific community pays great attention to the development of nanotechnology to make technological breakthrough in many fields of science and industry, in particular, in medicine and pharmacology. New carbon materials, such as fullerenes and nanotubes, though not being completely characterised so far as to their electrochemical properties, have stimulated a new trend in development of chemo- and biosensors [1-3]. A possibility of enzyme immobilization onto the surface of nanotubes,

(C) Institute of Molecular Biology and Genetics NAS of Ukraine, 2010 their application as electronic mediators for designing nanostructural biosensors are only few examples of effective usage of these materials in biosensorics. Numerous publications of the last decade are devoted to the development of electrochemical biosensors with bioselective membranes comprising both single- and multiwalled nanotubes which improves biosensor analytical characteristics [1-3]. In these works nanotube surface are usually modified with different protein-binding groups, mostly with carboxyl ones [1-5]. In this study we have explored multi-walled 
carbon nanotubes modified with $\mathrm{NH}_{2}$-groups (MWCNT- $\mathrm{NH}_{2}$ ) for creation of sensitive elements of the amperometric biosensor based on immobilized oxidoreductase (glucose oxidase). The electrochemical properties of such membranes have been studied.

Materials and methods. Materials. Glucose oxidase (GOx) (EC 1.1.3.4) from Aspergillus niger with activity of $271 \mathrm{U} / \mathrm{mg}$ was of "Gengyme Corp." (Germany) production, D-glucose, bovine serum albumin (BSA) and 50\% solution of glutaraldehyde (GA) - from "Sigma-Aldrich Chemie" (Germany), multi-walled carbon nanotubes modified with $\mathrm{NH}_{2}$-groups (MWCNT-NH ${ }_{2}$ ) - from "DropSens" (Spain), polyvinylpyrrolidone (PVP) - from "Merck" (Germany). Dimethyl sulfoxide (DMS), dimethyl formamide (DMFA) and other reagents were of domestic production and of analytical grade.

Biosensor design Screen-printed three-electrode transistors C220AT (further on - "gold electrodes") produced in «DropSens» (Oviedo, Spain) (Fig. 1A) were used in the work along with the PC-compatible portable bipotentiostate $\mu$ Stat 200 of the same firm. All electrochemical measurements were carried out in accordance with the producer's manual (for details see http://www.dropsens.com/en/inicio.html). To create laboratory prototypes of a biosensor, sensitive membranes were formed on the surface of working electrodes by glucose oxidase immobilisation.

Formation of sensor biomatrix Prior to immobilization, the surface of working electrode was treated with chromic mixture (saturated solution of potassium dichromate in concentrated sulfuric acid), thoroughly washed with distilled water and dried with ethanol. 2-mg portion of MWCNT- $\mathrm{NH}_{2}$ was suspended in $1 \mathrm{ml}$ of either DMS or DMFA, or aqueous solution of PVP $(100 \mathrm{mg} / \mathrm{ml})$ by a $30-\mathrm{min}$ sonication at room temperature in bath sonicator (Sonorex. Super RK 102 $\mathrm{H}$, Bandelin Electronic, Germany).

A sensitive matrix was formed by drop deposition of $1.7 \mu 1$ of mixture, contained $0.05 \%$ GOx, $6 \%$ BSA, $2 \%$ MWCNT- $\mathrm{NH}_{2}$ suspension and 5\% glycerol prepared in $25 \mathrm{mM}$ phosphate buffer, $\mathrm{pH} 7.0$ (further on "GOx-BSA-MWCNT-mixture"), onto the surface of a working electrode. Further immobilization of GOx was performed by covalent binding into protein gel in saturated GA vapour [6]. The electrodes were incubated for $30 \mathrm{~min}$ in GA vapour at room temperature and then were dried in the air for $30 \mathrm{~min}$ and washed three times with $25 \mathrm{mM}$ phosphate buffer, $\mathrm{pH}$ 7.0. The set of electrodes for comparison was prepared using the same mixture without nanotubes (further on "GOx-BSA-mixture"). For control, transducers without membranes were used as well as transducers with corresponding membranes without any enzyme.

Electrochemical measurement Study of voltage-current characteristic of electrodes and measurement of the amperometric biosensor signal were carried out using the device $\mu$ Stat 200 («DropSens», Spain) with appropriate software. The experimental setup included a glass cell for solution, an electromagnetic stirrer, a support stand, and a flexible connector between electric contacts of the sensor and the device $\mu$ Stat 200 (Fig. 1B).

Measurements were carried out in an open $2.5 \mathrm{ml}$ vessel containing $25 \mathrm{mM}$ phosphate buffer, $\mathrm{pH} 7.0$, at room temperature with intensive stirring. Before experiments, the electrode zone was put for $40 \mathrm{~min}$ into working buffer. The substrate concentration was varied by addition of certain aliquots of stock solutions. The biosensor signal to a certain substrate concentration was taken as an average of three measurements. The measurement error did not exceed 5\%. The voltage-current characteristic was detected in $25 \mathrm{mM}$ phosphate buffer with addition of $0.86 \mathrm{mM} \mathrm{H}_{2} \mathrm{O}_{2}$ or 20 $\mathrm{mM}$ glucose by the method of cyclic voltammetry at a rate of $100 \mathrm{mV} / \mathrm{s}$, repeating every measurement four times.

Results and discussion. Glucose oxidase is the most studied, stable and commercially available oxidoreductase which is widely used in development of sensors. Amperometric sensors, based on immobilized glucose oxidase, registrate hydrogen peroxide generated as a result of the reaction:

$$
\text { Glucose }+\mathrm{O}_{2} \stackrel{\text { GOx }}{\longrightarrow} \text { Gluconolacton }+\mathrm{H}_{2} \mathrm{O}_{2} \text {. }
$$

Hydrogen peroxide is decomposed on a working electrode with generation of $2 \mathrm{H}^{+}, 2 \mathrm{e}^{-}$and $\mathrm{O}_{2}$. Release of electrons results in change of the current at the 
"electrode-solution" interface in proportion to the glucose concentration.

In the preliminary investigation, cyclic voltammetric characteristics of gold electrodes DropSens without enzyme membranes were studied. It was determined that the rate of $100 \mathrm{mV} / \mathrm{s}$ was optimal for measurement by the method of cyclic voltammetry (Fig.2).

The typical cyclic voltammetric curves for gold electrodes DropSens without enzyme membranes in 25 $\mathrm{mM}$ phosphate buffer, $\mathrm{pH}$ 7.0, are shown in Fig. 3 (Fig. 3 , curves 1). Addition of hydrogen peroxide is seen to result in changing signal value at potential of $0.1-0.9$ $\mathrm{V}$ (Fig. 3A, curve 2) that testifies to $\mathrm{H}_{2} \mathrm{O}_{2}$ transformation on the electrode surface, while addition of glucose has no effect on the curve shape (Fig. 3B, curve 2). The potential of $0.8 \mathrm{~V}$ was taken as optimal for amperometric measurements. It was shown the absence of glucose oxidation/reduction at this potential (Fig. 3B, curve 2).

Elaboration of the method of formation of bioselective membranes, based on MWCNT- $\mathrm{NH}_{2}$ and GOx, consisted of 3 stages:

- option of a mode of tubes suspending;

- option of a technique of immobilisation of nanotubes and GOx on the electrode surface;

- exploration of electrochemical properties of the membrane developed.

Nanotubes were suspended using either DMS or DMFA, or aqueous solution of PVP $(100 \mathrm{mg} / \mathrm{ml})$ by ultrasound (see Materials and methods). In DMS variant no changes were revealed in tubes, while DMFA usage resulted in some increase in a tube volume. The best results, i.e. stable nanotubes suspending, were obtained with PVP. Moreover, PVP (apropos, used as a blood substitute and as a component of some medicines and cosmetic substances) is less toxic for the enzyme [7].

For formation of membranes based on immobilized GOx with usage of MWCNT-NH $\mathrm{N}_{2}$ we chose a method of binding by glutaraldehyde. Earlier, we have shown a possibility of creation of glucose biosensors on the basis of carbon fibers by means of immobilisation of glucose oxidase into protein gel (BSA) in GA vapour $[8,9]$. GA, being a bifunctional agent, produces intermolecular bonds between $\mathrm{NH}_{2}$-groups of substances forming Schiff bases. The reaction takes place under soft conditions which enables the enzyme to be kept in native state [10]. Besides, the binding of MWCNT- $\mathrm{NH}_{2}$ with the enzyme molecules should facilitate electron transfer between the enzyme active centre and the working electrode surface $[1,2]$.

In our preliminary experiments the mixture of GOx and suspended MWCNT was immobilized without BSA; low enzymatic activity of these membranes and fast washing-out of nanotubes was shown. Therefore, in further investigations BSA was added to the membrane mixture (see "Materials and methods").

In Fig. 4 the dependence of value of amperometric signal on glucose concentration for the biosensor based on gold electrodes DropSens and a GOx-BSA-MWCNT membrane is compared with that for control transducers. Addition of nanotubes to the enzyme membrane resulted in 1.5-time biosensor signal increase and wider linear range of glucose determination - from $0.1-4.0$ to $0.1-5.0 \mathrm{mM}$ (Table ).

Next, optimal working conditions were determined for the amperometric biosensor with gold electrodes and a GOx-BSA-MWCNT membrane. As seen from Fig. 5, A, at the phosphate buffer concentration exceeding $25 \mathrm{mM}$ the value of biosensor signal does not significantly changed which is an attribute of GOx-based biosensors [8, 11].

Therefore, $25 \mathrm{mM}$ phosphate buffer was used for the biosensor pH-optimum determination (Fig. 5B). According to the literature, glucose oxidase has a broad activity range of $\mathrm{pH} 4-7$ with $\mathrm{pH}$ optimum of 5.5 [12]. The biosensor $\mathrm{pH}$-optimum was shown to shift into alkaline zone, $\mathrm{pH} 7.0$, which could be caused by the changes in membrane local $\mathrm{pH}$ due to diffusion processes and accumulation of protons generated as a result of formation of $\mathrm{H}_{2} \mathrm{O}_{2}$ in the enzymatic reaction and its decomposition on the electrode [13]. A shorter optimal $\mathrm{pH}$ range can be also explained by limited capability of immobilized enzyme to change its tertiary structure in response to varying $\mathrm{pH}$.

Thus, it was shown that the GOx membrane with MWCNT ensured the enzyme activity and stability along with the capacity to function under conditions near-optimal for the native enzyme. Thereby, its application can improve biosensor analytical characteristics, i.e. high signal value and wide linear 


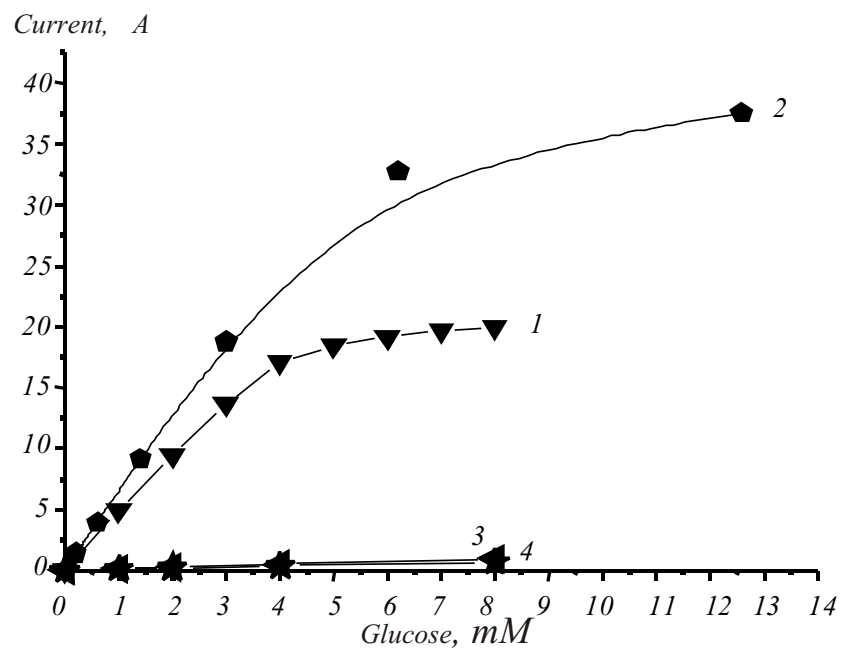

Fig. 4. Dependence of amperometric signal on glucose concentration in $25 \mathrm{mM}$ phosphate buffer, $\mathrm{pH} 7.0$, at applied potential $0.8 \mathrm{~V}: 1$ - biosensor based on membrane mixture GOx-BSA; 2 - biosensor based on membrane mixture GOx-BSA-MWCNT; 3 - control transducer - BSA membrane without enzyme; 4 - electrode without membrane.

range. Efficient functioning of biosensors at different working potential values is a main benefit anticipated in case of nanotubes application. This is important while measuring in biological liquids and foodstuffs, in particular, glucose to decrease an effect of interfering substances which can be oxidized or reduced at the potential value close to $0.8 \mathrm{~V}$. As seen from the cyclic
Comparison of analytical characteristics of amperometric biosensors for glucose determination based on gold electrodes DropSens and immobilized GOx

\begin{tabular}{c|c|c|c|c}
\hline \multirow{2}{*}{$\begin{array}{c}\text { Potential, } \\
\mathrm{V}\end{array}$} & \multicolumn{2}{|c|}{ GOx-BSA } & \multicolumn{2}{c}{ GOx-BSA-MWCNT } \\
\cline { 2 - 5 } & $\begin{array}{c}\text { Sensitivity, } \\
\mu \mathrm{A} / \mathrm{mM}\end{array}$ & $\begin{array}{c}\text { Linear range, } \\
\mathrm{mM}\end{array}$ & $\begin{array}{c}\text { Sensitivity, } \\
\mu \mathrm{A} / \mathrm{mM}\end{array}$ & $\begin{array}{c}\text { Linear range, } \\
\mathrm{mM}\end{array}$ \\
\hline$-0,5$ & - & - & 6,0 & $0,1-1,0$ \\
$-0,2$ & - & - & 5,4 & $0,1-1,0$ \\
$-0,2$ & 0,1 & - & 2,6 & $0,1-1,3$ \\
0,5 & 3,4 & $0,1-2,0$ & 4,3 & $0,1-2,0$ \\
0,8 & 4,8 & $0,1-3,0$ & 6,6 & $0,1-5,0$ \\
\hline
\end{tabular}

voltammetric curves for sensors based on immobilized mixtures GOx-BSA and GOx-BSA-MWCNT (Fig. 6,), the latter is characterized with signal variety in a wider range of potential (Fig. 6B,). It is confirmed by the calibration curves for glucose measurement at different working potentials (Fig. $6 \mathrm{~B}, \mathrm{D}$, Table ). Despite the sensor signal at $-0.5,-0.2 ; 0.2$, and $0.5 \mathrm{~V}$ is considerably lower compared to that at $0.8 \mathrm{~V}$, this value is quite sufficient for glucose measurement.

Investigation of stability of the biosensor with GOx-BSA-MWCNT-based membrane at dry storage at $4^{0} \mathrm{C}$ for 35 days showed (Fig. 7) that the membrane was quite stable as $85 \%$ of its initial activity remained.
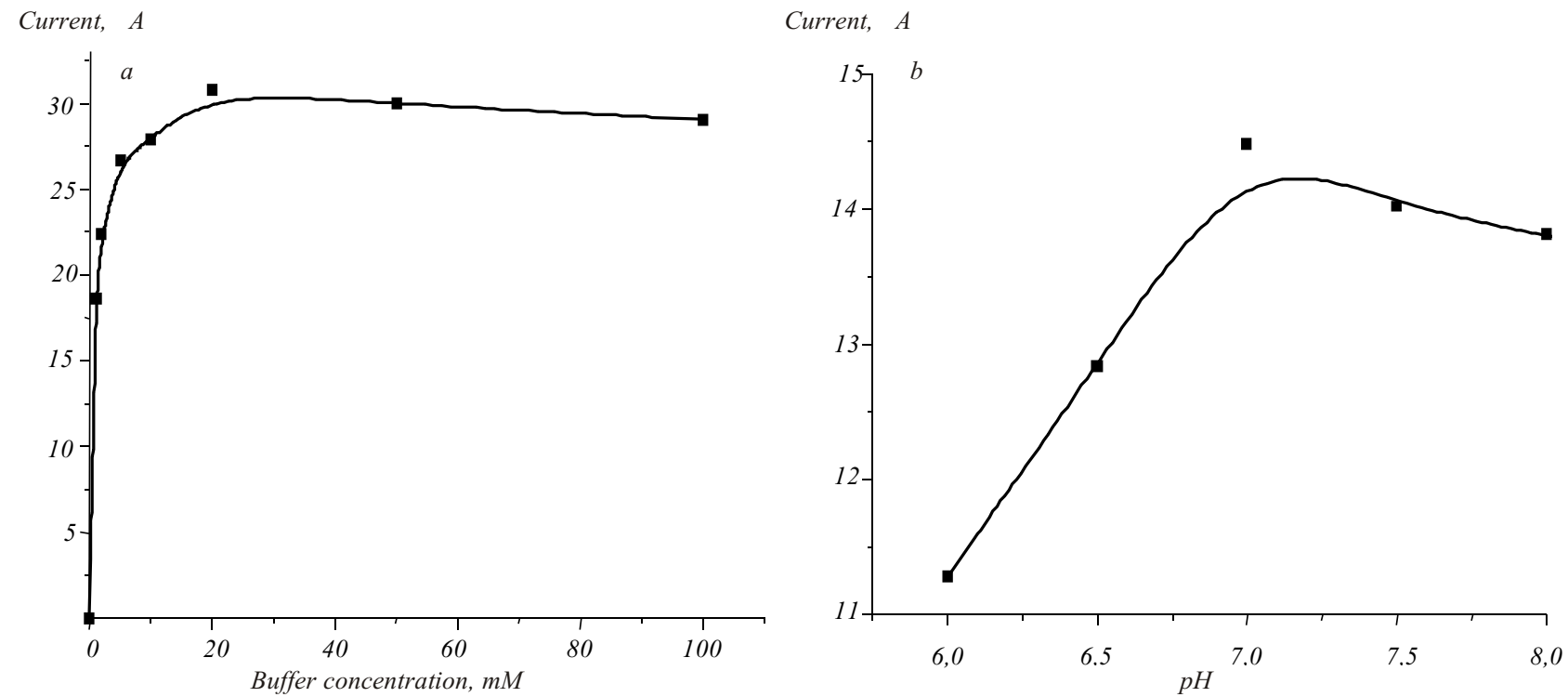

Fig. 5. Optimisation of conditions of measuring a signal of amperometric biosensor based on gold electrodes with GOx-BSA-MWCNT membrane. Dependence of biosensor response: $a$ - on concentration of phosphate buffer, $\mathrm{pH} 7.0 ; b-$ on $\mathrm{pH}$ of $25 \mathrm{mM}$ phosphate buffer. Measurements were carried out at $25^{\circ} \mathrm{C}$ after addition of $2.5 \mathrm{mM}$ glucose. 


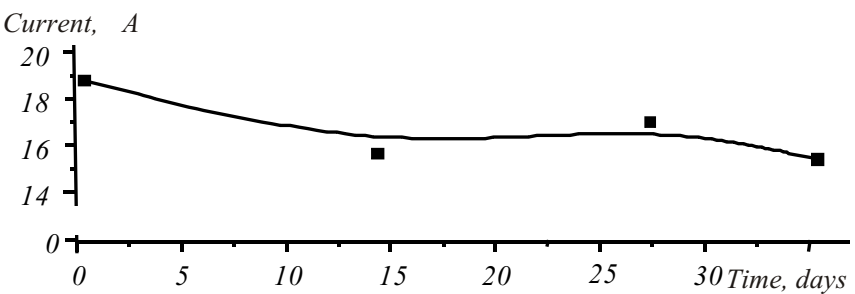

Fig. 7. Dependence of response of biosensor based on GOx-BSA-MWCNT membrane to glucose of constant concentration $(3 \mathrm{mM})$ on duration of dry storage at $+4^{\circ} \mathrm{C}$. Measurements were carried out at constant potential of $0.8 \mathrm{~V}$.

Noteworthy that the most remarkable changes in response were observed during first two weeks, and then the response stayed almost constant (a measurement error was about 7\%). Further improvement of biosensor stability is in progress.

Conclusion. The method of formation and immobilized of bioselective matrix, based on GOx with multi-walled carbon nanotubes (MWCNT) modified with $\mathrm{NH}_{2}-$ groups, on the surface of gold amperometric electrodes DropSens was elaborated. The optimal working conditions for membranes $(25 \mathrm{mM}$ phosphate buffer, $\mathrm{pH}$ 7.0) are found to be close to those for native enzyme. Including MWCNT into the membrane was shown to ensure the higher biosensor signal, wider linear range of measurable glucose concentrations, and determination of the substrate in a wide range of working potential.

\section{О. А. Білоіван, Н. С. Рогальова, Я. І. Корпан}

Оптимізація біоселективної мембрани амперометричного ензимосенсора на основі глюкозооксидази із застосуванням багатошарових карбонових нанотрубок, модифікованих аміногрупами

Резюме

Мета. Дослідити можливість застосування багатошарових карбонових нанотрубок, модифікованих аміногрупами (БНТ-NH $)$, для створення чутливих елементів амперометричного біосенсора на основі іммобілізованих оксидоредуктаз, зокрема глюкозооксидази (ГОД), та вивчити електрохімічні властивості отриманих мембран. Методи. Експерименти проведено з використанням амперометричних методів за допомогою приладу $\mu$ Stat 200 ("DropSens», Iспанія). Ферменти іммобілізували у випарах глутарового альдегіду. Результати. Оптимізовано метод формування біоселективної матриці біосенсора на основі іммобілізованої ГОД з БНТ- $\mathrm{NH}_{2}$ на поверхні золотих амперометричних електродів. Визначено оптимальні умови роботи біосенсора на ї̈ основі. Висновки.
Показано, щчо включення БНТ до біоселективної матриці біосенсора покращує його аналітичні характеристики: сприяє підвищенню величини сигналу та розширенню лінійного діапазону для встановлення рівня глюкози, дає можливість визначати субстрат у широких межах значень робочого потенціалу).

Ключові слова: багатошарові вуглецеві нанотрубки, модифіковані аміногрупами, амперометричний біосенсор, оксидоредуктази, глюкозооксидаза.

\section{О. А. Белоиван, Н. С. Рогалева, Я. И. Корпан}

Оптимизация биоселективной мембраны амперометрического энзимосенсора на основе глюкозооксидазы с использованием мультистеночных карбоновых нанотрубок, модифицированных аминогруппами

Резюме

Цель. Исследовать возможность использования мультистеночных карбоновых нанотрубок, модифицированных амино-

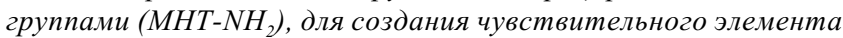
амперометрического биосенсора на основе иммобилизованных оксидоредуктаз, в частности глюкозооксидазы (ГОД), и изучить электрохимические свойства полученных мембран. Методы. Эксперименты проводили с использованием амперометрических методов с помощью прибора мStat 200 ( DropSens», Испания). Ферменты иммобилизовали в парах глутарового альдегида. Результаты. Оптимизирован метод формирования биоселективной матрииы биосенсора на основе иммобилизованной ГОД с МНТ-NH, на поверхности золотых амперометрических электродов. Определены оптимальные условия функиионирования биосенсора на ее основе. Выводы. Показано, что вкючение МНТ в состав биоселективной матриць биосенсора улучшает его аналитические характеристики: способствует увеличению величины сигнала и расширению линейного диапазона для нахождения уровня глюкозы, дает возможность определять субстрат в широких границах значений рабочего потенциала).

Ключевые слова: мультистеночные карбоновые нанотруб$\kappa и$, модифицированные аминогруппами, амперометрический биосенсор, оксидоредуктазы, глюкозооксидаза.

\section{REFERENCES}

1. Agui L., Yanez-Sedeno P., Pingarron J. M. Role of carbon nanotubes in electrochemical chemistry. A review // Anal. Chim. Acta.-2008.-622, N 1-2.-P. 11-47.

2. Sotiropoulou S., Gavalas V., Vamvakaki N. A., Chaniotakis N. A. Novel carbon materials in biosensor system // Biosensors and Bioelectronics.-2003.-18, N 2-3.-P. 211-215.

3. Sotiropoulou S., Chaniotakis N. A. Carbon nanotube arraybased biosensor // Anal. Bioanal. Chem.-2003.-375, N 1.P. 103-105.

4. Sheng $Q$., Zheng J. Bienzyme system for the biocatalyzed deposition of polyaniline templated by multiwalled carbon nanotubes: A biosensor design // Biosensors and Bioelectronics.-2009.-24, N 6.-P. 1621-1628.

5. Guan W. J., Li Y., Chen Y.-Q., Zhang X.-B., Hu G.-Q. Glucose biosensor based on multi-wall carbon nanotubes and screen 
printed electrodes. // Biosensors and Bioelectronics.-2005.21, N 3.-P. 508-512.

6. Starodub N. F., Hustochka L. N., Lazarenko A. V. BubryakO. A., Terentev A. G., El'skaya A. V. Integration of biological material in the electrochemical biosensor devices // Anal. Chem. USSR.-1990.-45, pt 2.-P. 1038-1044.

7. Kanukov V. N., Strekalovskaya A. D., Kil'kinov V. I., Bazarova $N$. $V$. Materials for modern medicine: Tutorial.-Orenburg: SOU GEA, 2004.-113 p.

8. Danyleyko L. V., Schuvailo O. N., Arkhypova V. M., Soldatkin A. P., Dzyadevych S. V. Development of amperometric enzyme biosensor based on carbon fibre electrode and immobilized glucose oxidase // Biopolym. cell.-2003.-19, N 1.P. 76-80.

9. Schuvailo O. N., Danyleyko L. V., Arkhypova V. M., Dzyadevych S. V., El'skaya A. V., Cespuglio R., Soldatkin A. P. Develop ment of microbiosensors based on carbon fibre for in vivo determination of glucose, acetylcholine and choline // Biopolym. cell.-2002.-18, N 6.-P. 489-495.
10. Immobilised cells and enzymes. A practical approach / Ed. J. Woodward.-Moscow: Mir, 1988.-215 p.

11. Shkotova L. V., Soldatkin A. P., Dzyadevych S. V. Adaptation of amperometric enzyme biosensor for glucose analysis in wine // Ukr. Biochem. J.- 2004.-76, N 3.-P. 114-121.

12. Davidova M. E., Kurova V. S., Cuhachyova M. V., Kupletskaya M. B., Riabov A. D., Netrusov A. I. Stability and catalytic properties of glucose oxidase from Penicilliu $\mathrm{fu}$ niculosum G-15 // Herald MSU, set 2, Chemistry.-2002.-43, N 6.-P. 366-370.

13. Trevan M. D. Immobilized enzymes.-Moscow: Mir, 1983.P. 47-51.

UDC 557.152.1+53.087.9:543.553

Received 07.10.09 
Figures to article by Biloivan O. A. et al.
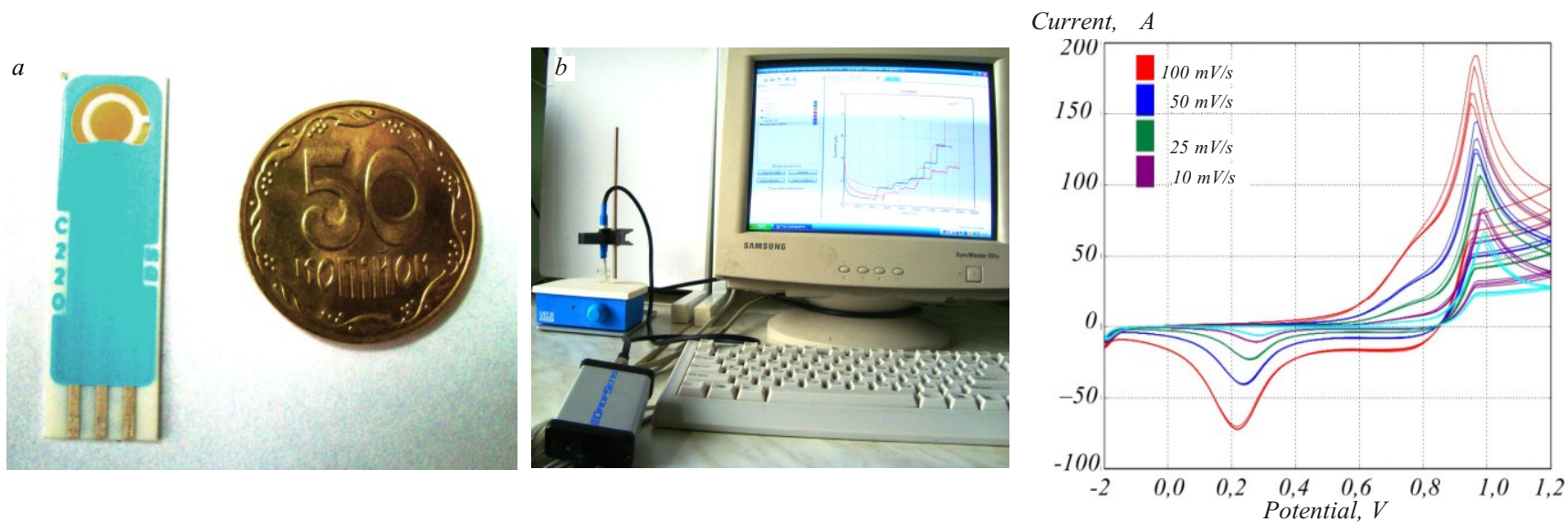

Fig. 1. General view of three-electrode amperometric transducer C220AT («DropSens», Spain) $(a)$ and experimental setup based on device $\mu$ Stat 200 («DropSens», Spain) $(b)$

Fig. 2. Cyclic voltammograms obtained in $25 \mathrm{mM}$ phosphate buffer, $\mathrm{pH}$ 7.0, for gold electrodes DropSens without enzymatic membranes at different scan rate.

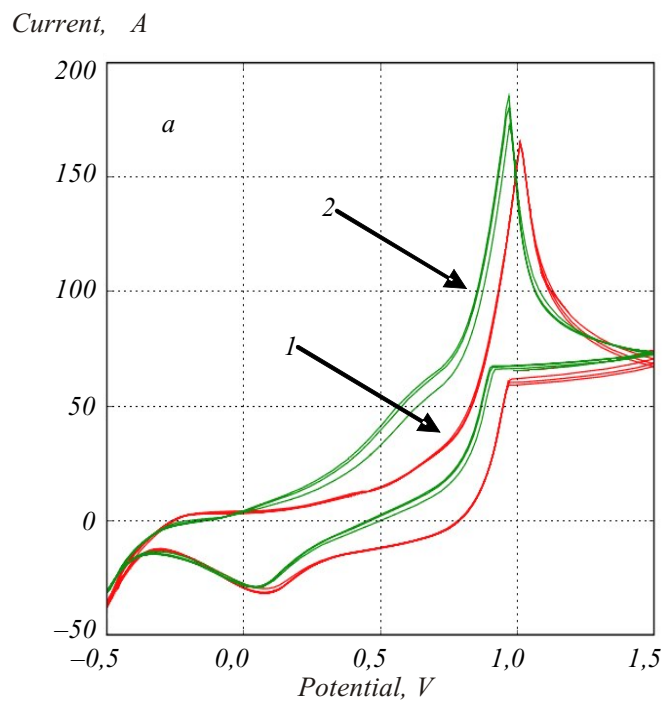

Current, $\mu A$

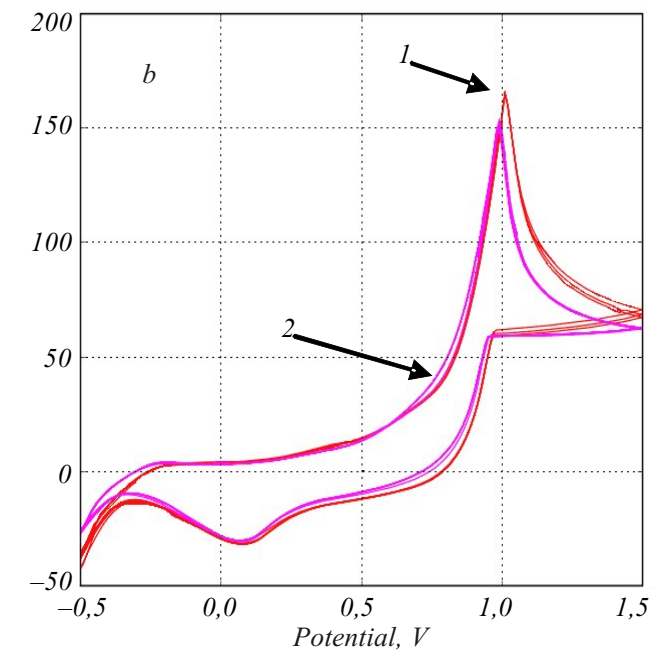

Fig. 3. Typical cyclic voltammetric curves obtained in $25 \mathrm{mM}$ phosphate buffer, pH 7.0, for gold electrodes DropSens without enzymatic membranes $(a, b$ - curves 1$)$ and after addition of $0.86 \mathrm{mM} \mathrm{H}_{2} \mathrm{O}_{2}(a$, curve 2$)$ and $20 \mathrm{mM}$ glucose $(b$, curve 2$)$. 


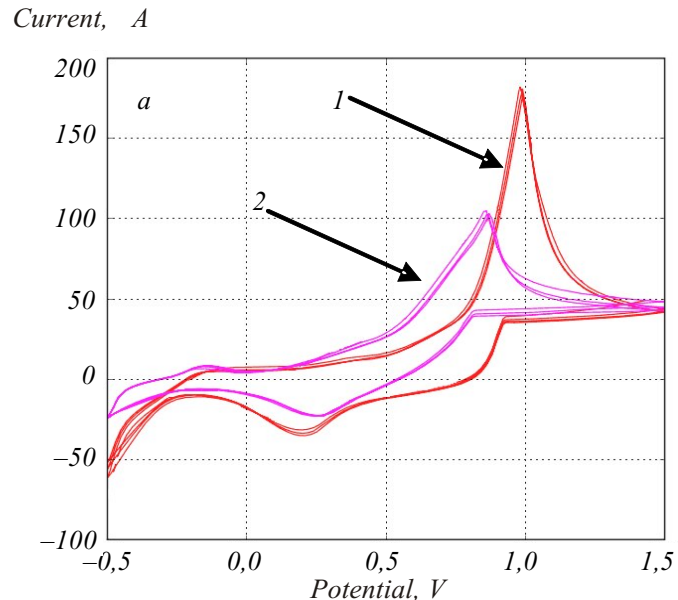

Current, $\mu A$

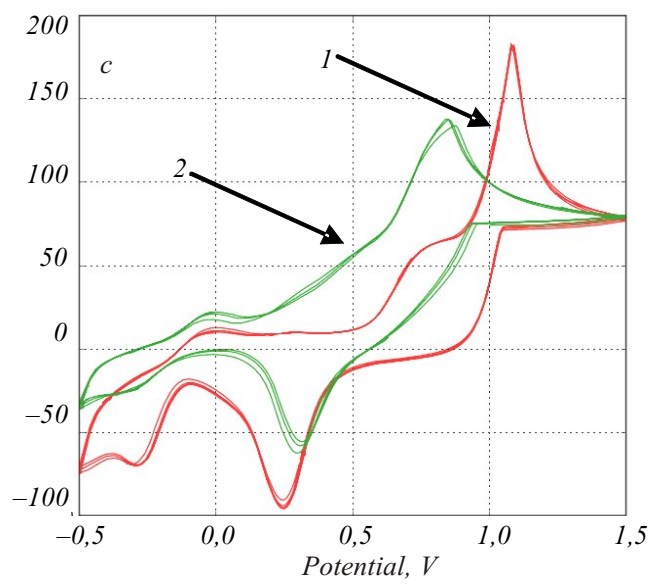

Current, $\mu A$

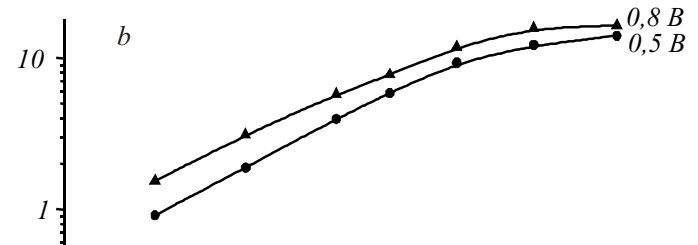

$0,2 B$

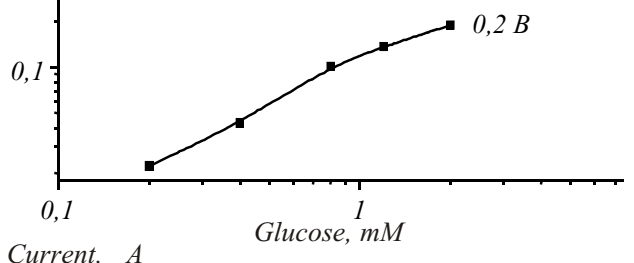

Current, $\mu A$

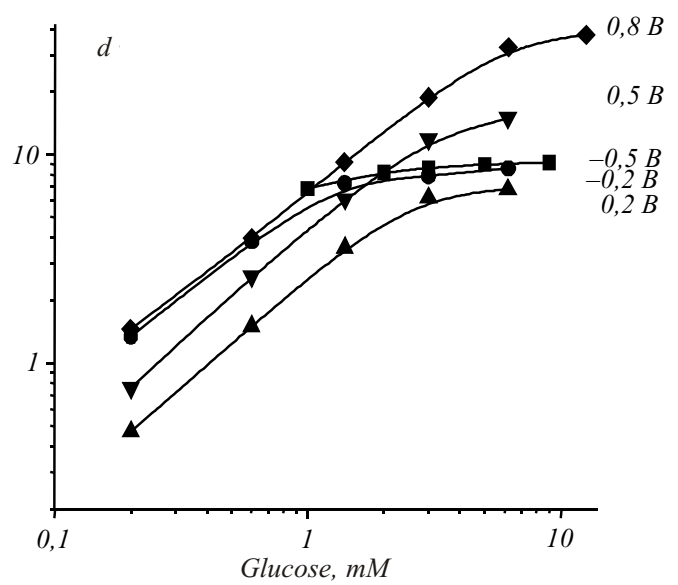

Fig. 6. Determination of optimal potential for glucose measurement with a biosensor: $a, b$ - based on bioselective membrane GOx-BSA; $c$, $d$ - based on bioselective membrane GOx-BSA-MWCNT (see "Materials and methods"); ( 1 - cyclic voltammogram obtained in 25 mM phosphate buffer, $\mathrm{pH} 7.0 ; 2$ - cyclic voltammogram obtained in $25 \mathrm{mM}$ phosphate buffer, $\mathrm{pH} 7.0$, in the presence of $20 \mathrm{mM}$ glucose). 